\title{
THE NEUROPATHOLOGICAL EFFECTS RESULTING FROM THE INTRATHECAL INJECTION OF CHEMICAL SUBSTANCES
}

\author{
By Lionel Wolman, M.A., M.D., Ph.D., M.R.C.P., M.C.Path., D.P.M. \\ Department of Neuropathology, Royal Infirmary, Sheffield
}

THERE are three main purposes for which chemical agents have been introduced into the spinal theca. These include the relief of pain or spasm, diagnosis and therapy. A large number of substances have been utilised with varying degrees of success. Although in the case of diagnostic and most therapeutic agents toxic actions on the central nervous system would not be permissible, the value of substances used for pain and spasm relief is dependent on their action on the nervous tissue, even though sometimes of a transitory nature. All these substances, however, are capable of inflicting damage on the nervous system, its coverings or to its blood supply if given in an incorrect amount or concentration, or if injected into a hypersensitive patient. The paraplegia which may be the sequel of this chemical trauma to the spinal cord and its nerve roots can be just as disabling as that resulting from physical injury.

I. Pain-Relieving Substances. (a) Spinal Anaesthetics. One of the earliest reports on the damage which can be inflicted by a spinal anaesthetic was made by Spielmeyer (I909) who described degeneration of dorsal and ventral nerve roots, together with marginal degeneration of the spinal cord well demonstrated by Marchi's stain, both in a human case and after experimental intralumbar injection of Novocaine. Similar effects have been observed with pentocaine and with percaine. Lundy et al. (1933) reported the effects in the dog of highly concentrated procaine given intrathecally. Degenerative myelitis following spinal anaesthesia was reported by Nonne and Denny (1928). In the patient described by Brain and Russell (1937) paralysis ensued one month after the anaesthetic with death $3 \frac{1}{2}$ months later. At autopsy, there was a necrotising pan-arteritis of pial vessels in the lumbar region and endophlebitis with extreme softening of the cord. Greenfield et al. (1955) described three cases with paralysis 7, 8 and 24 weeks after the anaesthetic. Vascular changes in leptomeningeal vessels were found in the lower thoracic and lumbosacral segments and consisted of adventitial fibrosis, replacement of the muscle of the media by collagen, breaking or thickening and reduplication of elastica and concentric fibrous thickening of the intima. There was fibrous thickening of the pia arachnoid with obliteration of the fluid spaces. Similar findings were recorded by Zeckel and Behr (I933), Donat (I937-8), Russell (1937), Kennedy et al. (1945, 1950) and Macken and Martin (1950). The lesions were considered to be due either to the spinal anaesthetic itself or, more probably, to some contaminant introduced with it into the spinal theca. The toxic acting could be either direct or allergic due to a hypersensitivity.

The possibility of contamination by detergents used for cleaning syringes was suggested by Winkelman et al. (1952, I953), while Rendell (1954) attributed the chemical meningitis following spinal anaesthesia to contamination of the subarachnoid space with phenolic disinfectants. A case of adhesive arachnoiditis 
involving the spinal cord and base of the brain with peripheral status spongiosus of the spinal cord following a spinal anaesthetic was attributed to a detergent by Paddison and Alpers (1954) who reviewed seven previous cases in the literature. The fact that a large variety of detergents and antiseptics of dissimilar chemical properties when introduced into the cerebrospinal fluid of monkeys could damage nervous structures and cause medial necrosis of pial vessels and fibrosis of the pia arachnoid, was demonstrated by Hurst (1955), who regarded the effect as a direct irritative action. Additional support for these observations came from similar experiments on monkeys by Denson and co-workers (1957) and by Joseph and Denson (1958). The dangers of inadequate washing of syringes which had been soaked in a solution of a phenolic disinfectant were stressed by Goldman and Sanford (1960) who described five patients in whom acute meningitis developed shortly after spinal anaesthesia for obstetric delivery. The cerebrospinal fluid in each case was purulent with a polymorph leucocytosis and pyrexia but no organism could be isolated. Fortunately all recovered without permanent neurological sequelae.

McLaurin et al. (I954) produced a chronic adhesive arachnoiditis in dogs by the intracisternal injection of pantopaque, kaolin and the two combined. This resulted in hydrocephalus and myelomalacia with multiple cavities communicating with the central canal, in the cervicothoracic part of the cord, within 4 to 6 weeks. The cavities were thought to be ischaemic from vessel compression in the meninges by the fibrosing arachnoiditis. The necrosis was located at the junction of white and grey matter in the posterior portion of the cord. This adhesive arachnoiditis is non-specific and can result from many intrathecal substances other than spinal anaesthetics, as well as from repeated subrachnoid bleeding or chronic meningitis.

The features of the damage resulting from a spinal anaesthetic are demonstrated in the following:

Case Report. A 55-year-old man had an operation for a torn internal semilunar cartilage of the right knee for which he was given a spinal anaesthetic (about $10 \mathrm{ml}$. of light Nupercaine, CIBA). On the following day he was unable to lift his legs as they felt numb and useless and he was doubly incontinent. The weakness became worse and he developed a complete spastic paraplegia with a sensory level at D8 and reflex bladder and bowel.

A cisternal myelogram was performed $2 \frac{1}{4}$ years later and this showed globulation and pocketing of the contrast medium with a block in the dorso-lumbar region at LI. A laminectomy carried out $2 \frac{1}{2}$ years after the spinal anaesthetic showed a dense fibrous adhesive arachnoiditis around cord and nerve roots with several large intrathecal cysts in the lower dorsal region. Four months later an intrathecal injection of alcohol was given at the upper end of the laminectomy scar. Io $\mathrm{ml}$. of 90 per cent. alcohol were injected and resulted in relaxation of abdominal musculature, numbness, tingling and weakness in the right hand. A further injection of $2 \mathrm{ml}$. was given 7 months later at L4-5 to relieve spasm in the calf and hamstring muscles. Obturator neurectomy, femoral nerve division, superficial peroneal nerve section and iliopsoas section were also carried out. His condition deteriorated with large pressure sores and bladder infection. Death occurred 9 years after the spinal anaesthetic and $5 \frac{1}{2}$ years after the second intrathecal alcohol injection.

At autopsy the dura was firmly adherent to the leptomeninges of the lower half of the spinal cord. The pia arachnoid over the whole length of the cord was grossly thickened. Microscopic examination of the cord showed marked changes at all levels examined. The upper cervical cord showed severe ascending degeneration of the sensory tracts in 
the medial posterior and antero-lateral columns with replacement gliosis. Extending downwards from $\mathrm{C}_{4}$ there was deymelination of the peripheral part of the cord increasing in extent and degree in the lower cervical segments where the myelin was reduced to a thin layer round the anterior horns of grey matter.

Extending from the level of Di down to DI I were two large loculated cavities lined by dense fibrous tissue of the thickened pia arachnoid on the posterior and lateral aspects of the cord (fig. I). Commencing at DI, the cord contained two glial lined cavities in the posterior horns of grey matter. These increased in size at $\mathrm{D}_{3}$ where they extended into both anterior horns with loss of nerve cells. At $\mathrm{D}_{5}$ the cavity had enlarged and had become $\mathrm{H}$ shaped replacing the grey matter (fig. 2) while at $\mathrm{D}_{7}$ the cord substance was reduced to a thin shell of demyelinated gliosed tissue enclosing a large cavity. Below this level the cavity was split into two being confined to the grey matter on each side of the midline, tapering out in the middle lumbar segments where the cord was reduced to a thin shell of gliotic tissue. The remainder of the lumbosacral cord had disappeared being replaced by a dense fibrous tag surrounded by the grossly fibrotic leptomeninges.

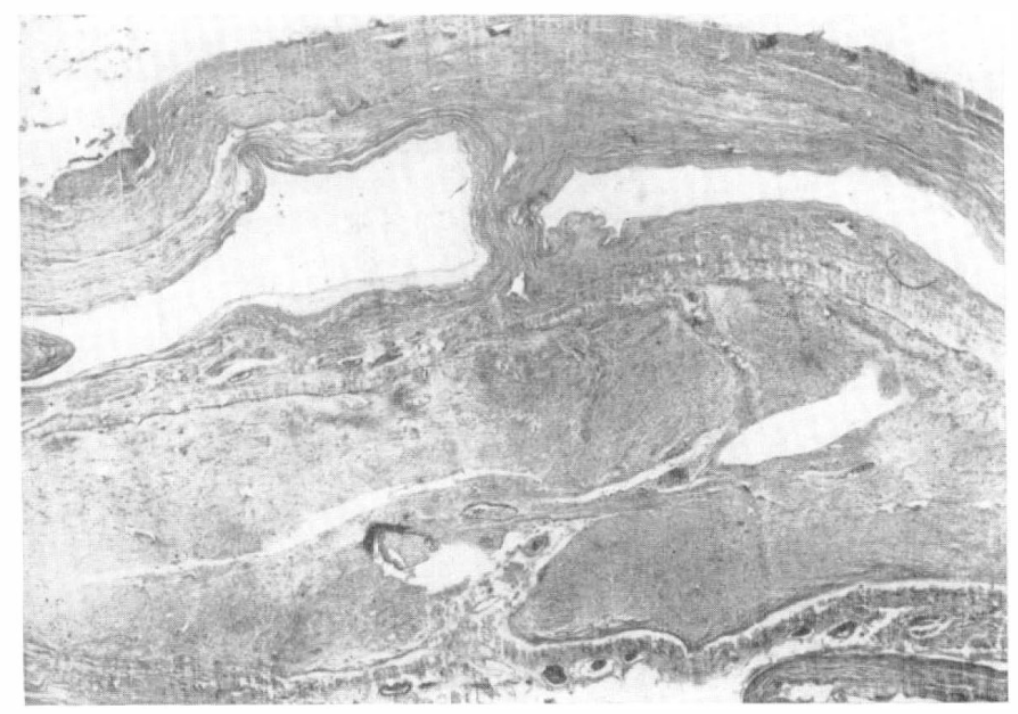

FIG. I

Transverse section of spinal cord at Di showing two cystic cavities in the thickened arachnoid on the posterior aspect and two glial lined cavities in the cord. Spinal anaesthetic 9 years previously. Intrathecal alcohol $3^{\frac{1}{2}}$ years later. Masson's trichrome. $\times$ II.

The thickened pia arachnoid surrounded the nerve roots, many of which showed patchy demyelination from C6 downwards, increasing in severity in the lower dorsal and lumbar segments. The nerve roots of the cauda equina were most severely demyelinated with only scanty residual myelin sheaths and axis cylinders and gross increase in endoneurial and perineurial connective tissue.

In the lower cervical segments and throughout the thoracic and lumbosacral segments there were changes in the meningeal arteries and veins. The internal elastic lamina of many arteries was fragmented or had disappeared (fig. 3) and there was replacement of the muscle coat by fibrous tissue. Some arteries showed concentric hyperplasia of the intima with narrowed lumen while in others there was complete replacement of the wall by collagen with residual elastica persisting. 


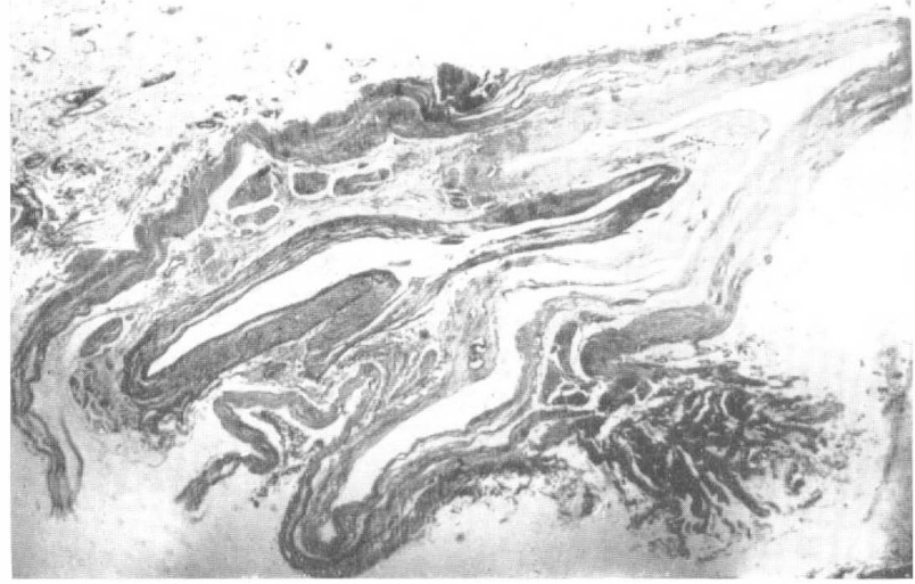

FIG. 2

Transverse section of spinal cord at $\mathrm{D}_{5}$ showing large $\mathrm{H}$-shaped cavity lined by dense gliosis in the cord with a cyst in the thickened arachnoid on its dorsolateral aspect. Masson's trichrome. $\times 7$.

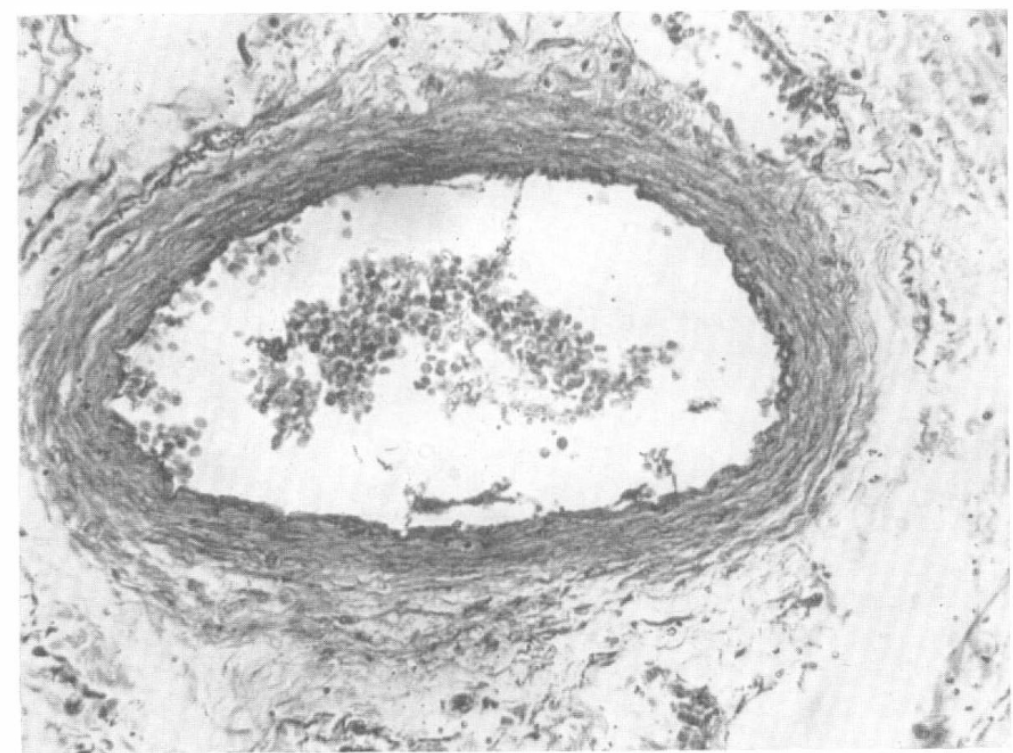

FIG. 3

Transverse section of anterior spinal artery at D8 showing connective tissue replacing muscle coat and disappearance of elastica apart from a short strand on its dorso-lateral aspect adjacent to the spinal cord. Elastic-Masson. $\quad \times 188$

Comment. Although it is difficult to sort out the effects of the spinal anaesthetic from those caused by the intrathecal alcohol so long after their administration, it seems likely that the arachnoid cysts in the thoracic region resulted from the 
arachnoiditis caused by the spinal anaesthetic as they were seen at laminectomy before alcohol was given. They were prominent in the case described by Woods and Franklin (I95I). It is also likely that the syringomyelic cavity associated with them at the same level resulted from a similar cause and developed as a consequence of necrosis of the grey matter secondary to the arterial involvement as occurred in the cases reported by Russell (1937), Nelson (I943), Kamman and Baker (1943), and Nielsen (1952). The vessel changes could be a direct toxic action of the spinal anaesthetic or, more likely, some contaminant, or it could be the result of a hyperallergic response as suggested by Greenfield et al. (1955). The peripheral demyelination of the cervical cord and the severe degeneration of nerve roots could be due to the alcohol, as similar changes were seen in other cases where it was used.

Although several of the earlier reports recorded histological changes in the cord both in experimental animals and in human material these were thought to disappear usually within a short period such as $12-48$ hours and as a rule within 90 days (Van Lier, I907: Spielmeyer, I908; Wossidlo, I908; Babcock, I928; Pitkin, I928; Davis et al., I93I; Koster \& Kasman, I934). Disintegration of axons of nerve roots and degeneration of the peripheral portion of the spinal cord were described by Lindemulder (1932) in patients dying soon after the administration of spinal anaesthetics. The cord examined by Brock et al. (I936), however, still showed a toxic myelopathy three months after the injection of nupercaine. There was extensive destruction of the myelin sheaths, axis cylinders and glia mostly in the periphery of the cord and at the posterior root entry zones with slight involvement of the ganglion cells of the anterior and lateral horns. In the three cases examined at autopsy ten days, one month and four months after operation reported by Ferguson and Watkins (I937-8) hyaline changes were seen in vessel walls with marginal pallor of the sacral cord and evidence of recent degeneration in sacral nerves. Much more marked changes were seen in the more recently reported cases where survival has been usually over two months and these resemble the changes described in the present case.

Thus there can be little doubt that severe neurological complications may follow spinal anaesthesia (Yaskin \& Alpers, I945; Nicholson \& Eversole, I946; Thorsén, I947; Bergner et al., I95 I; Michelsen, I952; Rosenbaum et al., I952; Williams, I954; Payne \& Bergentz, I956) resulting in two types of syndrome. One is a destructive process beginning either promptly with failure of the patient to recover fully from the effects of the anaesthetic or after a varying period of several hours or even months. The lesions consist of demyelination of spinal nerve roots especially of the cauda equina and of the peripheral margin of the lower spinal cord, chronic adhesive arachnoiditis progressing to gross thickening of the leptomeninges with obstructive hydrocephalus and arteritis of the pial vessels with cystic necrosis of the cord. The other syndrome is an acute meningeal inflammatory reaction which usually runs a benign course (Livingstone et al., I943) and has been called aseptic 'chemical' meningitis.

The case in which the pathological findings have now been described was the subject of a legal action brought in 1953 against the Ministry of Health and Messrs. Ciba. It was claimed that the small amount of a 5 per cent. solution of phenol in water that might have contaminated the anaesthetic by leaking through a hypothetical and invisible crack in an ampoule of cinchocaine (Nupercaine) was sufficient to cause severe arachnoiditis and consequent paraplegia. One of the foremost authorities of this country who gave expert evidence in the case considered 
that this was not so and that the paralysis was the result of hypersensitivity or idiosyncrasy on the part of the deceased to the particular spinal anaesthetic employed. Even though several cases of paraplegia following spinal anaesthesia had been previously recorded, the claim was regarded as established by the Court.

The histological examination confirmed the arachnoiditis, myelomalacia and arterial damage but the work of Hurst (1955) makes the possibility of a detergent used to clean needles and syringes more likely as an extraneous toxic substance, if such was the culpable factor. Cases of neurological complications following spinal anaesthesia have, however, antedated the development of modern detergents so that other extraneous agents or hypersensitivity cannot be excluded.

(b) Phenol. Maher (I955) introduced the use of phenol injected intrathecally for the relief of the chronic and severe pain occurring in some cases of cancer. The phenol was dissolved in glycerol and solutions of between 5 and ro per cent. gave a satisfactory therapeutic result. Later (1957) he used phenol dissolved in Myodil, Glaxo, (ethyl iodophenylundecylate, B.P.C.) which is opaque to X-rays and allows the patient to be positioned so that the solution lies over the nerve roots concerned with the pain. Two results of the injection were noted, one being a temporary or local anaesthetic effect and the other being chronic and sustained. Within one to two minutes of injection loss of sensibility and an almost complete local paralysis developed. These diminished greatly within 15 minutes. The chronic effect consisted of relief of pain with no or almost no permanent impairment of sensibility or movement. The interpretation of these results by Maher (I960) was that the phenol exerted a selective destructive action on small nonmedullated $\mathrm{C}$ fibres which were responsible for slow conduction of pain impulses with relative sparing of the large fast conducting A fibres responsible for touch, heat, cold, pain and motor impulses. Maher (1963) has also used intrathecal chlorocresol in the treatment of pain.

In cases of paraplegia with severe degrees of spasticity which were insusceptible to physical and medical therapy, Nathan (I959) successfully used intrathecal injection of phenol to obtain a chemical rhizotomy of the anterior roots. He used 20 per cent. phenol in glycerol or 25 per cent. phenol in myodil and the volume injected depended on the number of roots it was designed to affect. Favourable results using the method were also reported by Kelly and Gautier-Smith (I959), Liversedge and Maher (I960), Jervell (I96I), Koppang (1962), Pedersen and Juul-Jensen (1962, I965), and Schmidt et al. (1965).

In a study of the selective block of spinal nerve roots by phenol in the experimental animal, Nathan and Sears (I960) showed that small nerve fibres were more susceptible than large ones and that the effect was reversible to a certain extent. Similar results were obtained by Iggo and Walsh (I960), who suggested that the long term effect of phenol in patients may depend upon the extent to which the posterior root ganglion cells are destroyed. On the motor side, by analogy, it was thought that a suitable quantitative action on the anterior roots by phenol might block the small spasticity-mediating gamma fibres without disturbing the large alpha motor fibres responsible for voluntary movements.

In the seven cases reported by Nathan and Scott (1958) there was not any macroscopic abnormality which could be attributed to the injection of phenol in myodil. The meninges were not thickened and the nerve roots were of normal appearance. One case which had silver nitrate in phenol in glycerin injected intrathecally in the cervical region developed a marked leptomeningitis. No 
meningeal reactions were found in the cases reported by Berry and Olszewski (1963) and by André-Balisaux and Gonsette (1963).

In the limited post-mortem material available to Brown (1958) no local reaction to the injected material was seen, although four patients had well-marked arachnoiditis at the site of injection when the spinal cord was exposed at operation two to four weeks after treatment. The arachnoid was opaque, pink and adherent to the dura and cord for a distance of about two inches. Microscopically it was impossible to identify specific lesions of the cord or nerve roots apart from patchy degeneration in the posterior columns which may have been due to the action of phenol upon nerve roots.

The histological effects of phenol on the nerve roots where shown to the Physiological Society by Nathan, Sears and Smith (1958). Similar effects have been reported by Baxter and Schacherl (1962) in cats and by Berry and Olszewski (1963) in man. Smith (1964) found that the phenol exerted a direct destructive action on nerve roots and this was irrespective of the fibre size. The effect was most patchy due presumably to variations in concentration of phenol. This could result from pocketing due to surface tension in the cuffs of subarachnoid space along the nerve roots near the site where they penetrated the dura. No direct effects on the cord were seen. That the lesions involved both anterior and posterior roots and both thick and thin fibres was also noted by Pedersen and Reske-Nielsen (I965), who found the damage confined to fasciculi demarcated by connective tissue septa. Peripheral degeneration of nerve roots predominated in the material of André-Balisaux and Gonsette (1963).

In one of the three cases now reported similar severe effects on both dorsal and ventral nerve roots were seen after five days. In the second case, in addition a direct peripheral effect on the lumbo-sacral segments of the cord was roted after two months' survival and this was similar to that produced by other intrathecal chemical substances. The third case showed together with the changes in nerve roots, another spinal cord complication. A necrotic myelitis had resulted from thrombosis of pial vessels near the injection site. As no metastases were found in or near the spinal cord in this region it is most likely that this was an effect of chemical trauma.

Case Reports. Three patients treated with intrathecal phenol for severe pain from malignant disease were subsequently examined at autopsy.

Case 1. A 67-year-old man with a spontaneous fracture of the right humerus due to a metastasis from a carcinoma stomach. He was given three intrathecal injections:

I. Five weeks before death, at the level of $\mathrm{C}_{5}-6,2.5 \mathrm{ml}$. 5 per cent. phenol in Myodil.

2. One week later, at the level of C7-Di, 2 ml. of 20 per cent. phenol in Myodil and I $\mathrm{ml}$. of $\mathrm{I}$ in 80 silver nitrate in glycerine. X-ray showed that injection was both extradural and intradural, with penetration of both subdural and subarachnoid spaces.

3. Twelve days before death, at the level of $\mathrm{C}_{4}-5$, I ml. of 25 per cent. phenol in Myodil and $\mathrm{I} \mathrm{ml}$. of $\mathrm{I}$ in 80 silver nitrate in glycerin.

The first injection freed him from pain in the right forearm and hand while the second injection extended this area to involve the shoulder. After the third injection he developed weakness of the left leg which improved later in the day but over the next two days he lost the use of both legs and this persisted till death.

At autopsy no metastases were found in the central nervous system. The nerve roots of the lower cervical cord showed severe degenerative changes with demylination and 
numerous swollen, irregular, vacuolated and tortuous axis cylinders (fig. 4). Similar fibres were also seen in the posterior root ganglia where several of the nerve cells showed varying degrees of degeneration with proliferation of capsular cells and fenestration of their cytoplasm (fig. 5). These changes were more severe on the right.

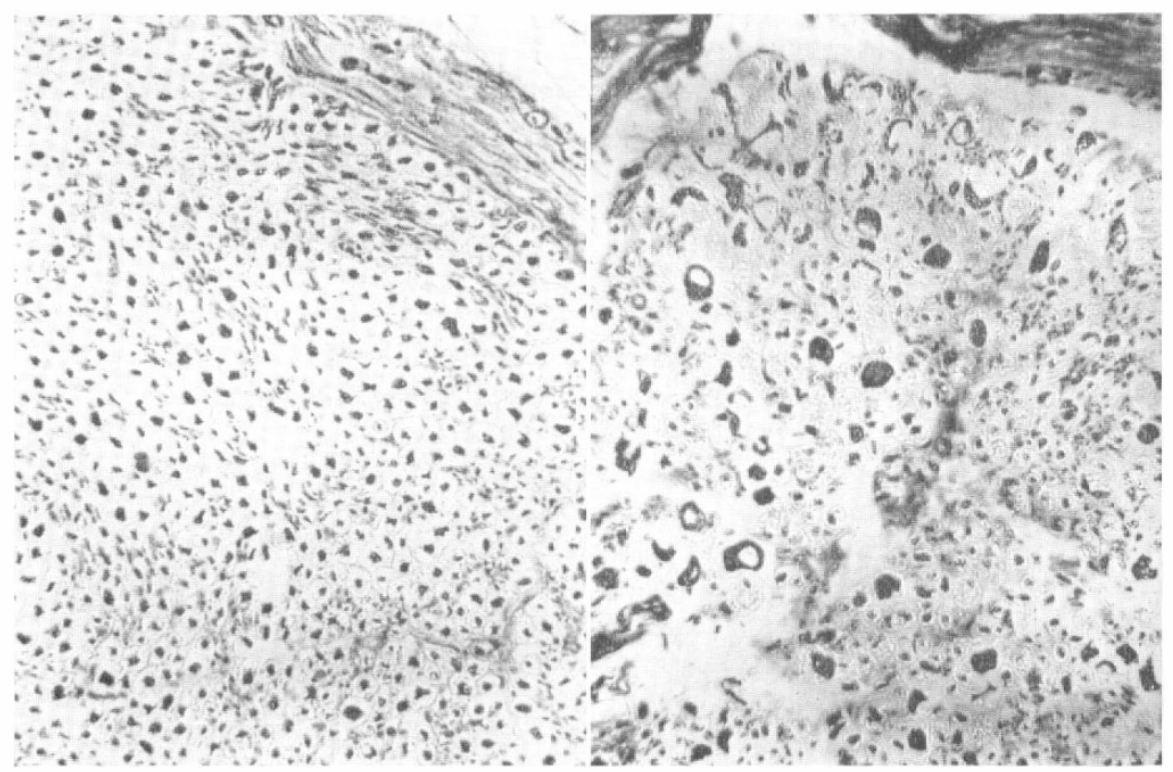

FIG. 4

Comparable transverse sections of (a) left and (b) right posterior nerve roots at $\mathrm{C}_{3}$ showing many swollen and vacuolated axis cylinders with reduction in their number on the right side. Silver. $\times$ I60.

The spinal cord was severely necrosed at the level of C7-8. Numerous histiocytes were present in the anterior horns of the necrotic grey matter while the white matter was severely demyelinated, although a few swollen axis cylinders could be recognised. Thrombosis of several veins in the pia arachnoid on the dorsal aspect of the cord had occurred as shown in Figure 7 (Wolman, 1965). At C6 thrombosed veins were also seen in the pia arachnoid on the dorsal aspect but only the dorsal half of the cord and the peripheral part of the white matter of the antero-lateral columns were involved.

Comment. Apart from the metastasis in the right humerus, no others were found in the arm, neck, spine or cord. Although the effect of microscopic deposits cannot be excluded, it seems likely that the nerve root and ganglion changes were due to phenol. The introduction of this substances into subdural and extradural spaces as well as into the subarachnoid space may have contributed to the severe ganglionic changes. The necrotic myelitis due to venous thrombosis seems to be a direct effect of the intrathecal phenol at this level.

Case 2. A 52-year-old man had a malignant carotid body tumour excised from the neck. Four years later he developed paraplegia with a sensory level at D7 due to an extradural metastasis which was removed. Owing to persistent painful spasms in the legs, $2 \mathrm{ml}$. of $\mathrm{I}$ in 20 phenol in glycerin was injected between the first and second lumbar vertebrae. The painful spasms ceased, the legs became flaccid and the bladder was paralysed. Death ensued two months later.

At autopsy there was a long thin extradural deposit of tumour on the posterior aspect 


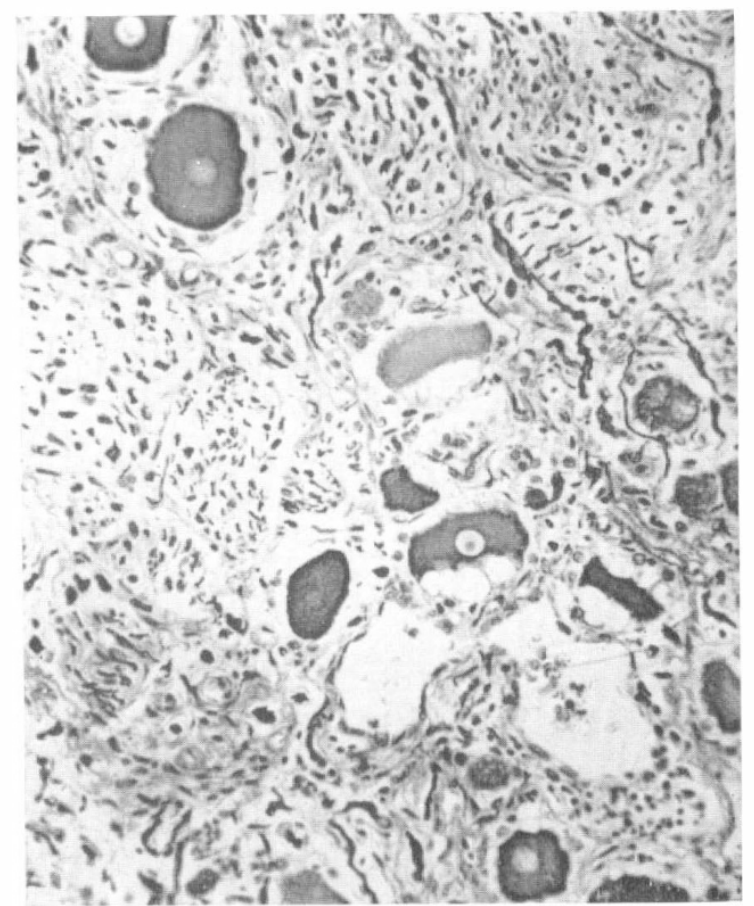

FIG. 5

Right posterior root ganglion at C6 showing fenestration of nerve cells and degeneration of many of the axis cylinders. Silver. $\times$ I5.

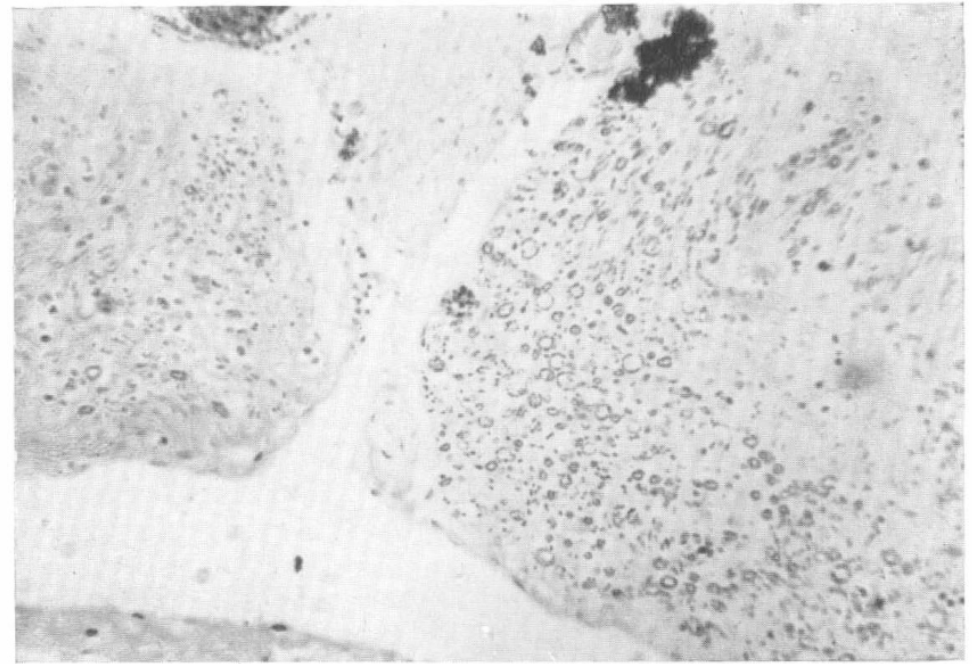

FIG. 6

Posterior nerve roots at $S_{3}$ showing severe demyelination of one root and less intense involvement of the other, two months after intrathecal phenol at LVI-2. Myelin. $\times$ I57. 
of the theca in the upper half of the thoracic spine. No penetration of dura had occurred and the cord appeared intact. Most of the nerve roots examined showed demyelination of varying intensity (fig. 6) with irregular swollen tortuous axis cylinders. This was maximal in the lumbosacral segments especially in the dorsal nerve roots but the ventral roots were also involved. The lumbosacral segments of the cord showed demyelination of the white matter round its periphery.

Comment. It seems likely that these effects were due to phenol as they had occurred in segments well below the extradural metastasis. The peripheral effect on the spinal cord was similar to that produced by other chemical substances.

Case 3. A man aged 53 developed intense pelvic and lower limb pain after removal of a bladder carcinoma three years previously. An injection of $\mathrm{I} \mathrm{ml}$. of 5 per cent. phenol in Myodil was given between L2 and 3. This relieved the pain but as it recurred on the following day further injections were made three days after the first. On this second occasion $2 \mathrm{ml}$. of 5 per cent. phenol in Myodil were injected in the epidural space between LI and 2 followed by I. $5 \mathrm{ml}$. of I in 20 phenol in glycerine with silver nitrate intrathecally. The pain was relieved but movement of the right leg became impaired. Death ensued five days later.

At autopsy the spinal cord appeared intact and there were no extradural deposits of tumour. The posterior lumbosacral nerve roots on both sides contained beaded irregular myelin sheaths and tortuous axis cylinders (fig. 7). Many of the nerves in the posterior root ganglia showed gross swelling and irregularity of axis cylinders while several of the nerve cells had undergone chromatolysis, others being small, hyperchromatic, and displaced by proliferation of capsular cells (fig. 8). Only a few fibres in some of the ventral roots on the right side showed degenerative changes.

Comment. Owing to the short period of survival of five days the changes in this case were less advanced but they do show that both dorsal and ventral nerve roots were affected.

Conclusions. These cases demonstrate the various ways in which phenol can act by damaging both dorsal and ventral nerve roots, the peripheral fibres in the spinal cord and the venous plexus on the cord surface.

The changes seen in the dorsal root ganglia were more difficult to interpret. Many axons appeared irregular, swollen and knobbed. Some nerve cells showed chromatolysis, others being hyperchromatic with either a ragged, corroded margin or fenestrated cytoplasm. Varying degrees of capsular proliferation occurred to form residual nodules of Nageotte (1907). These changes were bilateral in the two patients whose sensory ganglia were examined but were much more severe on the painful side to which the phenol had been directed in the first case.

Although theoretically nerve cell degeneration in the sensory root ganglia should only occur if the peripheral part of the neuron is damaged and this was borne out by absence of change in the ganglia in tabes dorsalis reported by earlier workers, some doubt exists as to its complete veracity. If the centrally directed part of the neuron is affected severely, especially near to the ganglion it seems very likely that there will be degenerative changes in the ganglia. Atrophic cells have been seen in the ganglia in severe cases of tabes and phenol pocketing in the cuffs of the subarachnoid space which extend along nerve roots could produce similar effects. As phenol was also injected extradurally and into the subdural space it could act as well on the peripheral axons of the ganglion cells.

A further difficulty in interpretation is the fact that degenerate nerve cells with residual nodules of proliferated capsular cells are occasionally seen in the ganglia of children and normal adults becoming abundant in old subjects and in such 

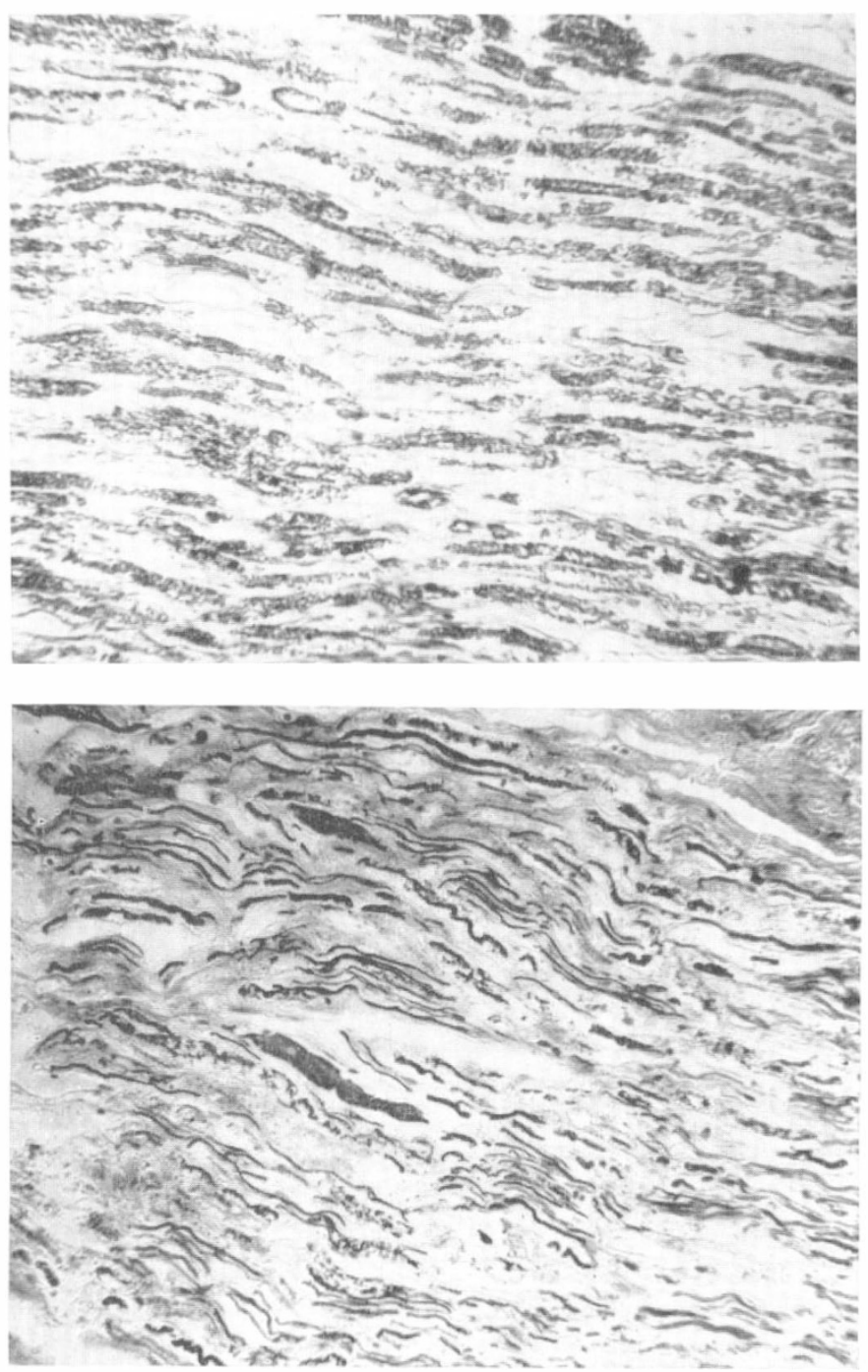

Fig. 7

(a) Longitudinal section of posterior nerve root at $\mathrm{L}_{3}$ showing patchy demyelination with fragmentation and irregularity of residual myelin sheaths. Myelin. $\times$ I 57 . (b) Longitudinal section of posterior nerve root at L2 showing swelling and tortuosity of axis cylinders. Silver. $\times \mathbf{2 0 6}$.

conditions as cancer, infections, tabes, amaurotic idiocy and alcoholism (De Castro, 1932). Thus the changes noted may have been due to the cancer rather than the phenol, although no tumour cells were seen in the nerve roots or ganglia or in the vicinity. The difference between the two sides were most suggestive that phenol was a contributory factor although this was also the side afflicted by pain from metastases causing the pathological fracture. 
Thus, although phenol is an improvement on alcohol as an agent for carrying out chemical rhizotomy, it still has some similar undersirable effects. These include its indiscriminate involvement of nerve fibres, the frequently transient relief of symptoms and its potentiality to produce arachnoiditis and vascular changes such as thrombosis. Its main advantage is the easy control of the extent of its spread when combined with a radio-opaque substance. The relative non-specificity of the action of phenol on nerve roots, involving fibres of various size and function leaving neighbouring fibres of the same type intact, was shown in the three cases

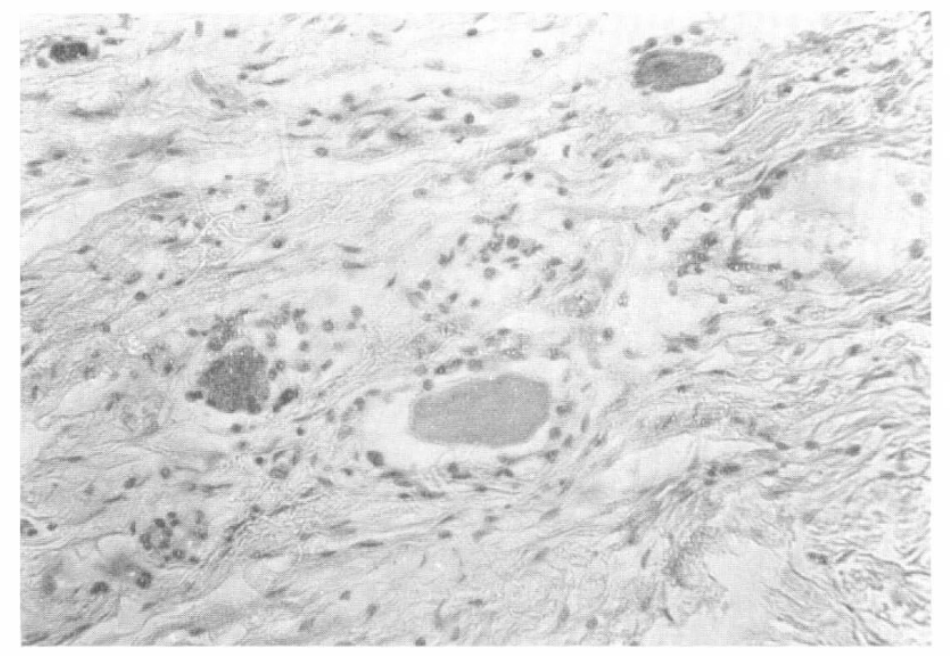

FIG. 8

Posterior root ganglion at $\mathrm{L}$ I showing proliferation of capsular cells round hyperchromatic nerve cell. Nissl. $\times 2$ IO.

examined. It indicates that in any attempt to get permanent and complete alleviation of symptoms, other neurological deficits will be almost certainly produced. Degeneration of nerve fibres in a similar irregular distribution was recently demonstrated in cats by Stewart and Lourie (1963), who showed that intrathecal phenol did not cause a selective destruction of smaller fibres. This was regarded by them as the probable explanation of the unpredictability of phenol in the treatment of pain or spasticity. Destruction of nerve fibres of all sizes and types scattered in bundles throughout the nerve roots was also shown by Nathan et al. (1965). Only rarely were all the fibres of one root destroyed and they believed that the explanation of the therapeutic success of phenol must depend on the number of fibres affected more than their qualitative type.

(c) Alcohol. The use of intrathecal alcohol for the relief of intractable pain, especially that associated with malignant disease, was first described by Dogliotti (193I). The method has been reviewed recently by Perese (1958). Although when injected below L2, it exerted its maximal effect on sensory nerves, in several cases loss of bowel and bladder control and paralysis of the legs ensued. Its use in paraplegics to relieve the violent muscular spasms often associated with involuntary defaecation, micturition and erection was first described by Guttmann (1946) 
and later by Boucher (1948), Sheldon and Bors (1948), and Cooper and Hoen (I949), and again by Guttmann (I953). In these paralysed patients the motor root involvement does not matter and probably contributes to the relief of spasm. Permanent motor weakness occurred in only two patients out of 322 with intractable pain from advanced malignant disease treated by subarachnoid alcohol by Kuzucu et al. (1966).

The pathological findings in the spinal cord and nerve roots in seven cases of traumatic paraplegia so treated with alcohol have been reviewed. These patients survived varying periods ranging from four months to nine and a half years after injection. Both dorsal and ventral roots were affected, although the dorsal roots were more severely involved and the fibres on the outer surface of the rootlets further away from the cord were more damaged than those on the inner aspect.

The earliest case seen was four months after injection, by which time there was extensive degeneration of the nerve roots with reparative fibrosis and intense gliosis round the periphery of the cord in the lower segments. Earlier changes were seen in the series of 12 cases of painful malignant disease reported by Gallager et al. (I96I). These consisted of swelling, irregularity and fragmentation of myelin sheaths and axis cylinders. Infiltration with polymorphs and macrophages occurred followed by proliferation of Schwann cells and fibroblasts.

In the cases surviving two years or longer after injection, the pia arachnoid was markedly thickened over the lumbosacral segments with many huge cysts surrounded by dense fibrous tissue. These cysts were predominantly beneath the dura in the external part of the thickened membrane but some were more deeply situated. Scattered foreign body giant cells and small collections of lymphocytes were present in this thickened membrane. Several pial vessels showed fragmentation of the elastica and intimal proliferation with narrowing of the lumen as seen in Figure I I (Wolman, I965). There was severe demyelination of the nerve roots of the cauda equina, affecting the dorsal roots more than the ventral, many being converted into dense fibrous bundles while others showed some intact centrally situated nerve fibres. The peripheral part of the lumbosacral cord showed demyelination with replacement gliosis, most marked on the dorsal aspect.

A direct action of the alcohol on nerve fibres was indicated by the severe destruction of peripheral fibres both in the cauda equina and in the spinal cord. In the most severely affected segments of the cord the only intact fibres were situated adjacent to the $\mathrm{H}$-shaped grey matter while in the least involved segments only a thin rim of peripheral fibres had disappeared.

In the description of the changes produced by alcohol the secondary effects in the cord due to Wallerian degeneration of the dorsal nerve-roots have not been described as they tended to obscure the direct effects. They were present in varying degree in all cases often being augmented by the degeneration resulting from the initial lesion causing the paraplegia. They involved the lateral part of the posterior columns and the postero-marginal tract.

The effect of the experimental injection of alcohol into the subarachnoid space of cats was studied by Aird and Naffziger (I935). They found widespread degeneration involving posterior rootlets, posterior funiculi, posterolateral tracts, anterior rootlets and antero-lateral columns. There was also slight but definite degeneration of pyramidal tracts and anterior commissure. Peyton et al. (I937) studied four patients with painful malignant disease who lived three to six months after injection. The posterior rootlets showed patchy demyelination. There was also demyelina- 
tion of the dorsal funiculus and the dorso-lateral fasciculus and the dorso-lateral fasciculus of Lissauer. The area of involvement of the dorsal column became displaced more medially in the upper cord segments. In only one case was there degeneration of the lateral spinothalamic tract on the contralateral side. Similar pathological findings were observed in the Io spinal cords studied by Hay et al. (1959). That alcohol can produce a toxic meningitis similar to that described under spinal anaesthetics was shown by Ver Brugghen (1942). Changes in the cerebrospinal fluid consisting of increase in pressure, albumin and leucocyte levels returning to normal after Io days was reported by Greenhill and Schmitz (1935). Paraplegia produced in a patient who was inadvertently given an intrathecal injection of $5 \mathrm{ml}$. of an 80 per cent. solution of ethyl alcohol was recorded by Koch (I947).

2. Diagnostic Agents. (a) Methylene Blue. Methylene blue has been used for many years by neurosurgeons in the investigation of cases of hydrocephalus, in which its introduction into the cerebral ventricles, has facilitated the recognition of block in the cerebrospinal fluid pathway and in the differentiation between communicating and non-communicating types. It has also been used to colour the cerebrospinal fluid in the investigation of cases of C.S.F. rhinorrhoea by injecting it into the spinal theca by the lumbar route. Although these procedures have been regarded as innocuous there are several recorded instances of deleterious effects (Brihaye \& Lorthioir, I957; Evans \& Keegan, I960; Arieff \& Pyzik, I960). Recently Wolman and Udall (I962) reported in detail the pathological changes in the central nervous system in a man who died from ascending paraplegia and respiratory failure $33 \frac{3}{4}$ hours after an intrathecal lumbar injection of the dye. These extended as high as the ventral surface of the midbrain (fig. 9). A direct toxic effect on nerve fibres of both the spinal cord (fig. IO) and nerve roots due to its affinity for axis cylinders was confirmed by injecting the dye into the spinal theca by lumbar or cisternal puncture in two monkeys. Similar effects were seen in the human case.

(b) Radio-opaque Contrast Media. No contrast substance used to date does not carry some risk and although there may be no immediate deleterious effects, the progressive development of chronic arachnoiditis and myelopathy many months or years later may give rise to a false sense of the innocuous nature of these agents. Thus the introduction of thorium dioxide (Thorotrast) was welcomed enthusiastically as a contrast medium for encephalography (Radovici \& Meller, I932-4), for myelography (Wurtmann, I933) and for ventriculography (Twining \& Rowbotham, I935; Guttmann, 1936). Freeman (1937) however reported distressing immediate reactions in laboratory animals. Spurling (1933) previously had reported good X-ray shadows using this medium in dogs but the animals unfortunately died. The delayed effects coming on after an average period of about eight years after myelography were reported in three cases by Maltby (1964). All had developed a severe and immediate systematic reaction, with a temperature elevation, within a few days of the initial intrathecal injection.

A similar latent period of several months has been reported after iodized oil (lipiodol) by Bucy and Spiegel (I943). Chronic arachnoiditis with hydrocephalus was recorded by Erickson and Baaren (1952) after pantopaque myelography. The morphological changes in the spinal cord, consisting of focal oedema localised to white matter, have been studied experimentally in the dog by Funkquist and Obel (I96I) after the subarachnoid injection of water-soluble contrast medium. 


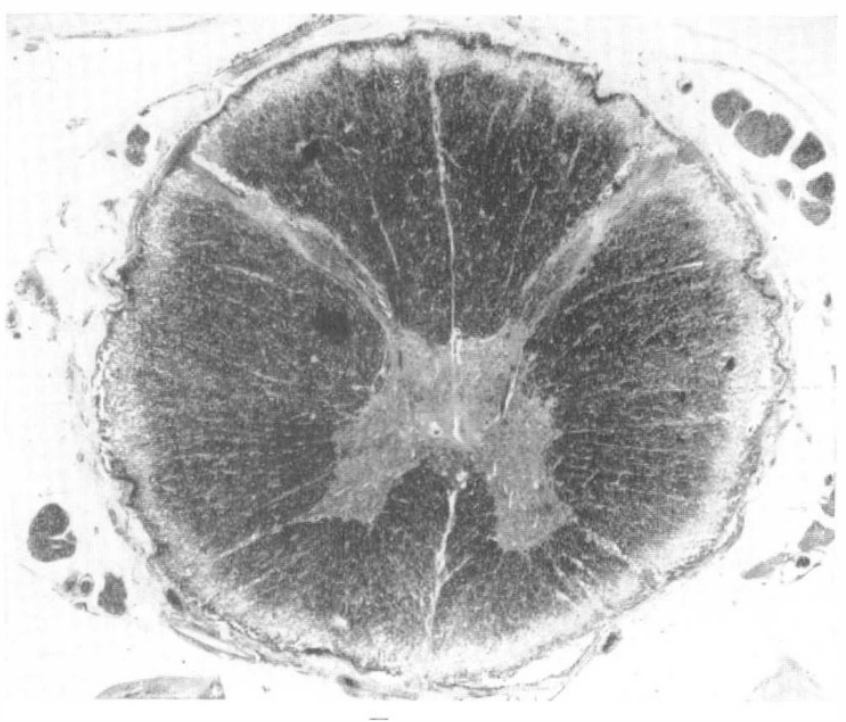

FIG. 9

Transverse section of thoracic cord showing peripheral demyelination. Lumbar intrathecal methylene blue given $33^{\frac{3}{4}}$ hours previously. Myelin. $\times$ II.

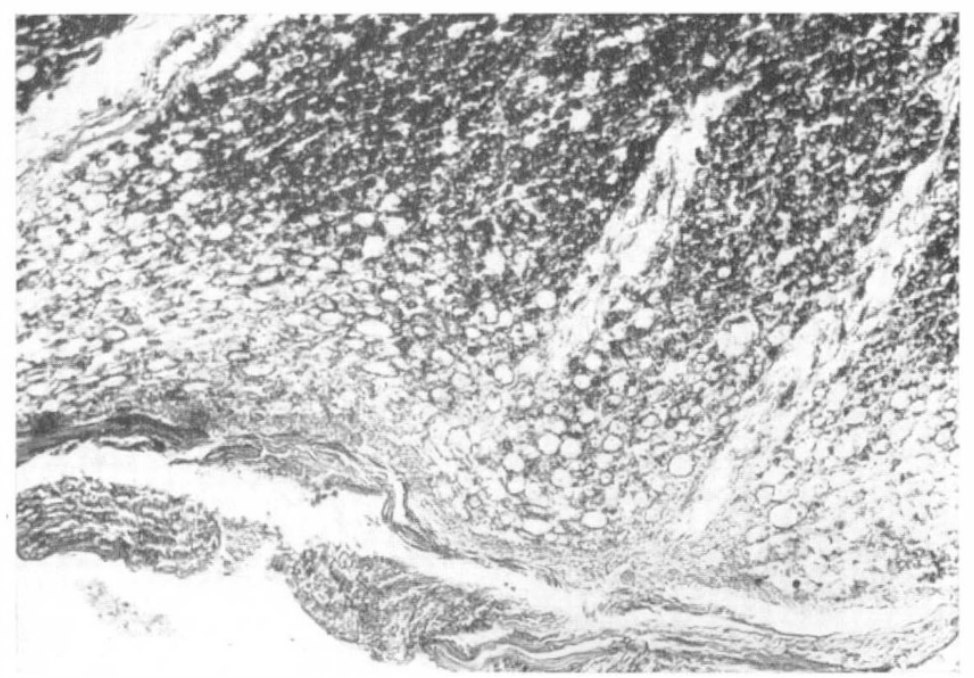

FIG. IO

Ventral surface of cervical spinal cord showing demyelination of superficial part with pallor of staining and vacuolation. Myelin. XIII. 
3. Therapeutic Substances. (a) Antibiotics. Although the benefits conferred by the careful use of intrathecal penicillin far outweigh the risks, the injection of more than I0,000 units in $10 \mathrm{ml}$. of saline is never safe and if bigger dosages are required these should never be more concentrated (Miller, 1964). The volume of the injected solution is an important factor in attaining widespread distribution as shown by Reiselbach et al. (1962) and this is what is required in the treatment of a diffuse meningitis. In the cases reported in the literature where paraplegia developed after therapy, this dosage or concentration was exceeded (Siegal, I945; Sweet et al., I945; Gerber et al., I946; Bradford, I946; Walker, I947; Millikan \& Sahs, I947; Edwards \& Kellsey, I950). Despite the extensive use of intrathecal penicillin there have been relatively few fatalities reported (Berne I950; Cohen, I952; Miller, I964). The principal pathological changes consisted of vascular congestion, subarachnoid extravasation of blood, perivascular cuffing of meningeal vessels by polymorphs and of parenchymal vessels with mononuclear cells, petechial haemorrhages and superficial necrosis.

The effects of intrathecal injections of streptomycin were reported by Ogura and Denst (1950).

(b) Sulphanilamide Preparations. Bailey (1945) recorded the effect of sulphonamide on the spinal cord. Peters (I95I) has reviewed the effects produced on the central nervous system by the intrathecal use of these drugs.

(c) Steroids. The effect of steroids on arachnoid adhesions has been studied experimentally by Feldman et al. (1955). Steroids have been used in the treatment of tuberculous meningitis to help in reducing the fibrotic response to the healing process (Choremis et al., I957). It has also been used in advanced adhesive arachnoiditis (Feldman \& Behar, I96I) and in pantopaque arachnoiditis (Sehgal et al., 1962). The effects of intrathecal cortico-steroids have been studied by Sehgal et al., (I963) who found no harmful effects apart from transient irritative phenomena. Problems arising in the use of intrathecal hydrocortisone have been discussed by Skinhoj and Buus (1959).

(d) Anti-tumour Agents. Intrathecal amethopterin has been used in carcinomatosis of the meninges and in Hodgkin's disease of the central nervous system (El-Ghaffar, I960).

(e) Other Substances. Various other substances have been tried either experimentally in animals or therapeutically in humans by the intrathecal route. Thus ephedrine was used by Brizzee and Wu (195I). Phenothiazine drugs have been tried in the mentally disordered (Verster, I963; Daneel, I966).

Paraplegia has also been recorded after treatment with sclerosing agents injected into the sacroiliac region for the correction of 'relaxed ligaments' (Schneider et al. 1959; Keplinger \& Bucy, 1960). A severe proliferative arachnoiditis with cyst formation was produced resembling that seen in the experimental animals (McLaurin et al., I954; Behar \& Feldman, I957). A similar leakage into the subarachnoid space of Efocaine (procaine, butyl amino benzoate, propylene and propylene glycol) used as a paravertebral anaesthetic block was presumed to be the cause of eleven cases of transverse myelopathy recorded by Plum (I955).

\section{SUMMARY}

The neuropathological effects produced by the intrathecal injection of various types of chemical agents have been reviewed. These substances have been utilised 
for the relief of pain and spasm, for diagnosis and for therapy. Several examples showing the resultant pathological changes have been studied and the effects recorded. The involvement of nerve roots and the periphery of the spinal cord indicates a similar direct toxic effect. After longer survival, fibrotic changes in the pia arachnoid and damage to pial vessels were conspicuous.

\section{RÉSUMÉ}

Les effets neuro-pathologiques produits par l'injection intra-rachidienne de différents types d'agents chimiques ont été passés en revue. Ces substances ont été utilisées dans le but de deminuer les douleurs, les spasmes, ainsi que dans le diagnostic et la thérapeutique.

Plusieurs exemples, montrant les altérations pathologiques qui en résultent, one été étudiés, ainsi que leurs effets. L'atteinte des racines nerveuses et de la périphérie de la moëlle indiquent un effet toxique direct similaire. Après une survie plus longue, les altérations fibreuses de la pie-mère et les dommages aux vaisseaux de celle-ci ont été démontrés.

\section{ZUSAMMENFASSUNG}

Der vorliegende Bericht enthält eine Review der neuropathologischen Folgen nach subarachnoidaler Injektion chemischer Substanzen. Diese Substanzen waren diagnostisch wie therapeutisch zur Behebung von Schmerzen angewandt worden. Mehrere Beispiele der resultierenden Veränderungen wurden studiert und die Resultate berichtet. Die betroffenen Nervenwurzeln und die Peripherie des Rückenmarks zeigen einen ähnlichen direkten toxischen Effekt. Bei längerer Überlebenszeit standen fibrotische Veränderungen der Pia-Arachnoidea sowie Verletzung der Piagefässe im Vordergrund der Schädigungen.

\section{REFERENCES}

Aird, R. B. \& Naffziger, H. C. (1935). West F. Surg. 43, 377.

AndRÉ-Balisaux, G. \& Gonsette, R. (1963). Acta neurol. belg. 3, 489.

AriefF, A. J. \& Pyzik, S. W. (1960). F. Amer. med. Ass. 173, 794.

BABCOCK, W. W. (1928). Amer. F. Surg. 5, 57 I.

BAIley, P. (I945). Ann. Surg. 122, 917.

BAXTer, D. W. \& SChaCherl, U. (1962). Canad. med. Ass. F. 86, I200.

Behar, A. J. \& Feldman, S. (1957). F. Neuropath. exp. Neurol. 16, 26I.

Bergner, R. P., Roseman, E., Johnson, H. \& Smith, R. W. (I95I). Anesthesiology, 12, 717. BERNE, R. M. (I950). New Eng. F. Med. 242, 8 I4.

BERRY, K. \& Olszewski, J. (1963). Neurology, 13, I52.

Boucher, R. (1948). Bull. Acad. nat. Méd. 132, 362.

BRADFORD, F. K. (1946). Med. Rec. 40, I5I4.

Brain, W. R. \& Russell, D. S. (I937). Proc. Roy. Soc. Med. 30, IO24.

BRIHAYE, J. \& LORTHIOIR, J. (I957). Acta chir. belg. 56, 312.

BRIZZEE. K. R. \& WU, J. J. (I95I). F. Neuropath. clin. Neurol. I, 234.

Brock, S., Bell, A. \& Davison, C. (1936). F. Amer. med. Ass. 106, $44 \mathrm{I}$.

BRown, A. S. (1958). Lancet, 2, 975.

BuCY, J. \& S Siegel, I. J. (I943). F. Amer. med. Ass. 122, 367.

Choremis, C., Papadatos, C., Gargoulas, A. \& Drosos, C. (I957). F. Pediat. 50, I 38.

CoHEN, M. M. (1952). F. Neuropath. exp. Neurol. II, 335.

COOPER, I. S. \& HoEN, T. I. (1949). F. Neurosurg. 6, I87.

Daneel, A. B. (1966). S. Afr. Med. F. 40, 47.

Davis, L., Haven, H., Givens, J. H. \& Emmett, J. (193i). F. Amer. med. Ass. 97, i78I.

De Castro, F. (1932). Cytology and Cellular Pathology of the Nervous System. Vol. I. Ed. W. Penfield. Section 3, p. I25. New York: Paul B. Hoeber Inc.

Denson, J. S., Joseph, S. I., Koons, R. A., Murry, W. E. \& Bisonnette, H. W. (I957). Anesthesiology, 18, I43.

Dogliotti, A. M. (I93I). Rev. neurol. $2,485$.

Donat, R. (1937-8). Dtsch. Z. ges. gerichtl. Med. 29, 34.

EDwards, W. M. \& Kellsey, D. C. (I950). U.S. armed Forces Med. F. 1, 806.

El-Ghaffar, Y. A. (1960). Cancer, 13,677.

ERICkson, T. C. \& BaARen, H. J. (I952) Trans. Amer. neurol. Ass. 77, I34. 
Evans, J. P. \& Keegan, H. R. (1960). F. Amer. med. Ass. 174, 856.

Feldman, S. \& Behar, A. J. (I96I). Neurology, II, 25 I.

Feldman, S., Behar, A. J. \& Samueloff, M. (I955). Arch. Neurol. Psychiat. 74, 68I.

Ferguson, F. R. \& Watkins, K. H. (1937-38). Brit. F. Surg. 25, 735.

Freeman, W. (1937). Arch. Neurol. Psychiat. 38, 340.

Funkeuist, B. \& Obel, N. (I96I). Acta Radiol. 56, 449.

Gallager, H. S., Yonezawa, T., Hay, R. C. \& Derrick, W. S. (i96i). Amer. F. Path. 38, 679 .

Gerber, A., Boldrey, E., McCorkle, H. J. \& Wariner, H. (i946). F. Neurosurg. 3, 533.

Goldman, W. W. \& Sanford, J. P. (I960). Amer. J. Med. 29, 94.

Greenfield, J. G., Rickards, A. G. \& Manning, G. B. (i955). F. Path. Bact. 69, 95.

Greenhill, J. P. \& Schmitz, H. E. (1935). F. Amer. med. Ass. I05, 406.

Guttmann, L. (1936). Handbuch der Neurologie, Vol. VII/2, p. 424. Ed. Bumke und Foerster, Publ. T. Springer, Berlin.

Guttmann, L. (i947). Proc. Roy. Soc. Med. 40, 2 I 9

Guttmann, L. (1953). Brit. History of World War II, Vol. Surgery, 457; London: H.M. Stationery Office.

Hay, R. C., Yonezawa, T. \& Derrick, W.S. (1959). J. Amer. med. Ass. 169, I3I5.

Hurst, E. W. (1955). F. Path. Bact. 70, I67.

IGGo, A. \& WALSh, E. G. (I960). Brain, 83, 70 I.

JERVELL, J. (I96I). T. norske Laegeforen. 8I, 9I I.

Joseph, S. I. \& Denson, J. S. (1958). F. Amer. med. Ass. I68, I330.

Kamman, G. R. \& Baker, A. B. (I943). Minn. med. 26, 786.

Kelly, R. E. \& GaUtier-Smith, P. C. (I959). Lancet, 2, I IO2.

Kennedy, F., Effron, A. S. \& Perry, G. (1950). Surg. Gynec. Obstet. 91, 385.

Kennedy, F., Somberg, H. M. \& Goldberg, B. R. (I945). F. Amer. med. Ass. I29, 664.

Keplinger, J. E. \& BuCy, P. C. (I960). F. Amer. med. Ass. 173, I 333.

Косн, G. (1947). Med. Klin. 42, 3 I8.

Koppang, K. (I962). Acta neurol. scand., Suppl. 3, 38, 63.

Koster, H. \& Kasman, L. P. (I934). Amer. F. Surg. 25, 277.

Kuzucu, E. Y., Derrick, W. S. \& Wilber, S. A. (i966). F. Amer. med. Ass. I95, 54I.

Lindemulder, F. G. (1932). F. Amer. med. Ass. 99, 2 Io.

Liversedge, L. A., MAHER, R. M. (I960). Brit. med. F. 2, 3 I.

Livingstone, H., Wellman, V., Clark, D. \& Lambros, V. (i943). Surg. Gynec. Obstet. 77, 2 I 6.

Lundy, J., Essex, H. \& Kernohan, J. W. (I933). F. Amer. med. Ass. roi, I540.

Macken, J. \& Martin, F. (I950). Mschr. Psychiat. Neurol. I19, I29.

Mclaurin, R. L., Bailey, O. T., Schurr, P. H. \& Ingraham, F. D. (i954). Arch. Path.57, I 38 .

MAHER, R. M. (I955). Lancet, I, I8.

MAHER, R. M. (I957). Lancet, I, I6.

MAHER, R. M. (I960). Lancet, $\mathbf{I}, 895$.

MAHER, R. M. (1963). Lancet, I, 965.

Maltby, G. L. (I964). New Engl. F. Med. 270, 490.

Michelsen, J. (I952). Neurology, 2, 255.

Miller, H. (I964). Proc. Roy. Soc. Med. 57, I 46.

Millikan, C. H. \& Sahs, A. L. (I947). F. Iowa St. med. Soc. 37, I99.

Nageotte, J. (1907). Anat. Anz., Fena, 31, 225.

Nathan, P. W. (1959). Lancet, 2, ro99.

Nathan, P. W. \& Scott, T. G. (I958). Lancet, I, 76.

Nathan, P. W. \& Sears, T. A. (I960). J. Physiol. 150, 565.

Nathan, P. W., Sears, T. A. \& Smith, M. C. (I958). F. Physiol. 140, 3 IP.

Nathan, P. W., Sears, T. A. \& Smith, M. C. (I965). F. neurol. Sci. $2,7$.

Nelson, J. (I943). Arch. Neurol. Psychiat. 50, I.

Nicholson, M. J. \& Eversole, U. H., (i946). F. Amer. med. Ass. 132, 679.

Nielsen, J. M. (1952). Trans. Amer. neurol. Ass. 77, I74.

NoNNE, M. \& DENNY, H. (I928). Wien. klin. Wschr. 4I, I IO2.

Ogura, G. I. \& Denst, J. (I950). Dis. Chest. I8, 29 I.

Paddison, R. M. \& Alpers, B. J. (1954). Arch. Neurol. Psychiat. 71 , 87.

Payne, J. P. \& Bergentz, S. E. (I956). Lancet, I, 666. 
Pedersen, E. \& Juul-Jensen, P. (1965). Neurology, 15, 256.

Pedersen, E. \& Juul-Jensen, P. (I962). Acta neurol. scand., Suppl. 3, 38, 69.

Pedersen, E. \& Reske-Nielsen, E. (1965). Acta Neuropath. 5, i 12.

Perese, D. M. (1958). Arch. Surg. 76, 347

Peters, G. (I95I). Spezielle Pathologie der Krankheiten des zentralen und peripheren Nervensystems. Stuttgart: Georg Thieme.

Peyton, W. T., Semansky, E. J. \& Baker, A. B. (1937). Amer. F. Cancer, 30, 709.

Pitkin, G. P. (1928). Amer. F. Surg. 5, 537.

Plum, F. (I955). Myelititis and Myelopathy. In Clinical Neurology, Ed. by A. B. Baker. 2nd Edit. p. I726. New York: Hoeber-Harper.

Radovici, A. \& Meller, O. (I932). Bull. Acad. Méd. (Paris), ro7, 3 I 4.

Radovici, A. \& Meller, O. (I933). Klin. Wschr. 12, 429.

Radovici, A. \& Meller, O. (I934). Presse Méd. 42, I 53.

Reiselbach, R. E., Di Chiro, G., Freireich, E. J. \& Rall, D. P. (i962). New Engl. F. Med. 26, I 273.

Rendell, C. M. (I954). Anaesthesia, 9, 28I

Rosenbaum, H. E., Long, F. B., Hinchey, T. R. \& Trufant, S. A. (1952). Arch. Neurol. Psychiat. 68, 783.

Russell, D. S. (I937). F. Path. Bact. 45, 357.

Schmidt, S. A., Cain, H. D. \& MEad, S. (1965). Paraplegia, 3, 152.

Schneider, R. C., Williams, J. J. \& Liss, L. (1959). F. Amer. med. Ass. 170, 768.

Sehgal, A. D., Gardner, W. J. \& Dohn, D. F. (I962). Cleveland Clin. Quart. 29, I77.

Sehgal, A. D., Tweed, D. C., Gardner, W. J. \& Foote, M. K. (1963). Arch. Neurol. 9, 64.

Sheldon, C. H. \& Bors, E. (I948). F. Neurosurg. 5, 385.

Siegal, S. (1945). F. Amer. med. Ass. 129, 547.

SkinhoJ, E. \& BuUs, O. (I959). Dan. med. Bull. 6, 259.

SMith, M. C. (I964). Brit. F. Anaesth. 36, 387.

SPIElMEYeR, W., (1908), Mïnch. med. Wschr. 55, I629.

SPIELMEYER, W., (I909). Neurol. Zbl. 28, 69.

Spurling, R. (1933). Med. Ann. D.C. 2, 279.

Stewart, W. A. \& Lourie, H. (I963). F. Neurosurg. 20, 64.

Sweet, K. K., Dumoff-Stanley, E., Dowling, H. F. \& Lepper, M. H. (i945). F. Amer. med. Ass. I 27, 263.

Thorsén, G. (I947). Acta chir. scand., Suppl. I2 I, 95, I.

Twining, E. W. \& Rowbotham, G. F. (1935). Lancet, 2, 122.

VAN LIER, E. H. (1907). Beitr. klin. Chir. 53, 4I3.

Ver Brugghen, A. (1942). Med. Clin. N. Amer. 26, 255.

Verster, J. P. (1963). S. Afr. med. F. 37, I086.

Walker, A. E. (1947). Arch. Neurol. Psychiat. 58, 39.

Williams, J. M. (1954). F. int. Coll. Surg. 22, I8.

Winkelman, N. W. (I952). Neurology, 2, 284.

Winkelman, N. W., Gotten, N. \& Scheibert, D. (1953). Trans. Amer. neurol. Ass. 78, i 5.

Wolman, L. (1965). Paraplegia, 2, 2 I 3.

Wolman, L. \& Udall, V. (I962). Methylene Blue and The Nervous System. Paper and demonstration at 22nd Meeting of British Neuropathological Society, Bristol. (In Press.)

Woods, W. W. \& Frankin, R. G. (I95I). Calif. Med. 75, I96.

Wossidlo, E. (1908). Arch. klin. Chir. 86, I0I7.

Wurtmann, O. (1933). Dtsch. Z. Chir. 238, 529.

YASkin, H. E. \& Alpers, B. J. (I945). Ann. intern. Med. 23, I84.

ZeCkel, A. \& Behr, E. (1933). Psychiat. neurol. Bl., Amst. 37, 57. 